\title{
Cathepsin D Deficiency Induces Lysosomal Storage with Ceroid Lipofuscin in Mouse CNS Neurons
}

\author{
Masato Koike, ${ }^{1}$ Hiroshi Nakanishi, ${ }^{2}$ Paul Saftig, ${ }^{3}$ Junji Ezaki, ${ }^{5}$ Kyoko Isahara, ${ }^{1}$ Yoshiyuki Ohsawa, ${ }^{1}$ \\ Walter Schulz-Schaeffer, ${ }^{4}$ Tsuyoshi Watanabe, ${ }^{1}$ Satoshi Waguri, ${ }^{1}$ Satoshi Kametaka, ${ }^{1}$ Masahiro Shibata, ${ }^{1}$ \\ Kenji Yamamoto, ${ }^{2}$ Eiki Kominami, ${ }^{5}$ Christoph Peters, ${ }^{6}$ Kurt von Figura, ${ }^{3}$ and Yasuo Uchiyama ${ }^{1}$

\begin{abstract}
1Department of Cell Biology and Neurosciences, Osaka University Graduate School of Medicine, Suita, Osaka 565-0871, Japan, 2Department of Pharmacology, Faculty of Dentistry, Kyushu University, Fukuoka 812-8582, Japan, ${ }^{3}$ Center for Biochemistry and Molecular Cell Biology and ${ }^{4}$ Department of Neuropathology, Göttingen University, 37073 Göttingen, Germany, ${ }^{5}$ Department of Biochemistry, Juntendo University School of Medicine, 2-1-1 Hongo, Tokyo, Japan, and ๔Medizin, Universitätsklinik, Abteilung I, Freiburg University, 79106 Freiburg, Germany
\end{abstract}

Cathepsin D-deficient (CD-/-) mice have been shown to manifest seizures and become blind near the terminal stage [approximately postnatal day $(P)$ 26]. We therefore examined the morphological, immunocytochemical, and biochemical features of CNS tissues of these mice. By electron microscopy, autophagosome/ autolysosome-like bodies containing part of the cytoplasm, granular osmiophilic deposits, and fingerprint profiles were demonstrated in the neuronal perikarya of CD-/- mouse brains after P20. Autophagosomes and granular osmiophilic deposits were detected in neurons at PO but were few in number, whereas they increased in the neuronal perikarya within days after birth. Some large-sized neurons having autophagosome/autolysosome-like bodies in the perikarya appeared in the CNS tissues, especially in the thalamic region and the cerebral cortex, at P17. These lysosomal bodies occupied the perikarya of almost all neurons in
CD-/- mouse brains obtained from P23 until the terminal stage. Because these neurons exhibited autofluorescence, it was considered that ceroid lipofuscin may accumulate in lysosomal structures of CD-/- neurons. Subunit $c$ of mitochondrial ATP synthase was found to accumulate in the lysosomes of neurons, although the activity of tripeptidyl peptidase-I significantly increased in the brain. Moreover, neurons near the terminal stage were often shrunken and possessed irregular nuclei through which small dense chromatin masses were scattered. These results suggest that the CNS neurons in CD-/- mice show a new form of lysosomal accumulation disease with a phenotype resembling neuronal ceroid lipofuscinosis.

Key words: cathepsin D; knockout mouse; CNS neurons; ceroid lipofuscin; subunit c of mitochondrial F1FOATPase; lysosomal storage; neuronal ceroid lipofuscinosis
Cathepsin D (CD) (EC 3.4.23.5) is a representative aspartic proteinase in lysosomes and is widely distributed in various tissue cells of mammals (Barrett and Kirsche, 1981). The expression level of CD varies depending on the tissue, whereas neurons in CNS tissues possess abundant CD (Whitaker and Rhodes, 1983; Reid et al., 1986). It has been suggested that CD participates in various biological events such as the degradation of various brain-specific antigens, aging, and certain pathological situations in brain tissues (Banay-Schwartz et al., 1987; Matus and Green, 1987; Nakanishi et al., 1994, 1997; Cataldo et al., 1995). However, the physiological significance of CD has remained unknown, not only in the case of CNS but also in peripheral tissues. Through the generation of $\mathrm{CD}$-deficient $(\mathrm{CD}-/-)$ mice, it has recently been shown that $\mathrm{CD}$ is involved in limited proteolysis rather than bulk proteolysis (Saftig et al., 1995). The CD-deficient mice are born normally but die at postnatal day (P) $26 \pm 1$ because of massive intestinal necrosis, thromboembolia, and lymphopenia.

Different from cathepsin D and other lysosomal proteinases detected in the CNS tissues, the only proteinase that shows sub-

\footnotetext{
Received March 1, 2000; revised May 15, 2000; accepted June 28, 2000.

This work was supported by Grant-in-Aids on Priority Areas from the Ministry of Education, Science, Sports and Culture, Japan.

M.K. and H.N. contributed equally to this study.

Correspondence should be addressed to Yasuo Uchiyama, Department of Cell Biology and Neurosciences, Osaka University Graduate School of Medicine, 2-2 Yamadaoka, Suita, Osaka 565-0871, Japan. E-mail: uchiyama@anat1.med.osakau.ac.jp.

Dr. Peters' present address: Albert-Ludwigs-Universität Freiburg, Institut für Molekulare Medizin und Zellforschung, Freiburg 79106, Germany.

Copyright (C) 2000 Society for Neuroscience $0270-6474 / 00 / 206898-09 \$ 15.00 / 0$
}

strate specificity is tripeptidyl peptidase-I (TPP-I); its deficiency has been demonstrated to cause one type of neuronal ceroid lipof uscinoses (NCLs). NCLs are a closely related group of recessively inherited neurodegenerative diseases (Carpenter, 1988; Rider and Rider, 1988; Rider et al., 1992). They are characterized pathologically by massive lysosomal storage with an autofluorescent lipopigment in neurons and a wide variety of extraneuronal cells that show characteristic ultrastructural appearances (Berkovic et al., 1988; Boustany et al., 1988; Wisniewski et al., 1988). Biochemical analysis of the storage bodies has shown that the major stored component is protein (Palmer et al., 1986). In many types of NCLs except for the infantile form of NCL, subunit $\mathrm{c}$ of the mitochondrial F1F0ATPase is stored in the cells (Palmer et al., 1989; Fearnley et al., 1990; Hall et al., 1991; Kominami et al., 1992).

During the course of our studies on morphological as well as functional changes in CNS tissues of $\mathrm{CD}-/-$ mice, we first noticed that the mice show neurological phenotypes with seizures near the terminal stage. In the present study, we therefore examined the morphological, immunocytochemical, and biochemical features of CNS tissues in CD $-/-$ mice. The most striking feature found in the CNS neurons was the storage of autophagosome/autolysosomelike bodies with part of the cytoplasm, granular osmiophilic deposits, and fingerprint profiles; they emitted autofluorescence and were immunopositive for cathepsin B and subunit $\mathrm{c}$ of mitochondrial F1F0ATPase, indicating that they contained ceroid lipofuscin. These bodies appeared at P1 but were very small in number, whereas they largely accumulated in the neuronal perikarya after P20, suggesting that CD plays an important role in the lysosomal proteolysis in CNS tissues. Moreover, the CNS neurons in the $\mathrm{CD}-/-$ mice show a new form of lysosomal accumulation disease similar to a certain type of NCL. 


\section{MATERIALS AND METHODS}

\section{Animals}

The heterozygous (+/-) mice (Saftig et al., 1995) were transferred to the Institute of Experimental Animal Sciences (Osaka University Graduate School of Medicine) and kept in conventional facilities. Selection of $\mathrm{CD}-/-$ mice from littermates obtained by heterozygous coupling was performed according to the method of Saftig et al. (1996) in which template genomic DNA isolated from tail biopsies was examined by cathepsin D-exon 4-specific PCR with primers of MCD14 (5'-AGACTAACAGGCCTGTTCCC-3' $)$ and MCD15 (5' - TCAGCTGTAGTTGCTCACATG- $3^{\prime}$ ). Heterozygous mice used as control animals in the present study showed no pathological phenotypes when examined by histological, immunocytochemical, and biochemical methods.

\section{Antisera}

Rabbit antibodies against rat cathepsins B and L, cathepsin D, and subunits $\beta$ and $\mathrm{c}$ of mitochondrial F1F0ATPase were produced and purified by affinity chromatography, as reported previously (Kominami et al., 1984, 1985, 1992; Bando et al., 1986; Ohsawa et al., 1993). Rabbit antibodies against the C-terminal fragment of human TPP-I (Ezaki et al., 1999) was used for the detection of mouse TPP-I.

\section{Morphological analysis}

Sampling. CD $-/-$ and $\mathrm{CD}+/-$ littermates at P1, P7, P8, P14, P17, P23, P24, P25, and P26 were deeply anesthetized with pentobarbital $(25 \mathrm{mg} / \mathrm{kg}$, i.p.) and fixed by cardiac perfusion using $2 \%$ paraformaldehyde $-2 \%$ glutaraldehyde buffered with $0.1 \mathrm{M}$ phosphate buffer (PB), $\mathrm{pH} 7.2$, for ordinal electron microscopy ( $n=3$ for each), using $4 \%$ paraformaldehyde buffered with PB containing $4 \%$ sucrose for light microscopic immunohistochemistry $(n=3$ for each $)$ and using $4 \%$ paraformaldehyde and $0.1 \%$ glutaraldehyde buffered with PB for immunoelectron microscopy ( $n=3$ for each). For electron microscopy brains, spinal cord and retinal samples were excised from the mice, cut into small pieces, and further immersed in the same fixative at $4^{\circ} \mathrm{C}$ overnight. After they were washed thoroughly with the same buffer containing $7.5 \%$ sucrose, samples were post-fixed with $1 \%$ $\mathrm{OsO}_{4}$ in the same buffer containing $7.5 \%$ sucrose, at $4^{\circ} \mathrm{C}$ for $2 \mathrm{hr}$, and the CNS tissue was block-stained with a $2 \%$ aqueous solution of uranyl acetate for $1 \mathrm{hr}$. The tissues then were dehydrated with a graded series of ethanol and embedded in Epon 812.

For light microscopic immunohistochemistry, brain and various peripheral (body) tissues were quickly removed from the mice and further immersed in the same fixative for $2 \mathrm{hr}$. The samples from each mouse were processed for paraffin embedding, cut at $5 \mu \mathrm{m}$ with a microtome, and placed on silan-coated glass slides.

For electron microscopic immunocytochemistry, the brain tissue was quickly excised from the mice, and cerebral cortical, hippocampal, thalamic, and cerebellar cortical regions were separated from each brain, cut into small pieces, and further immersed in $4 \%$ paraformaldehyde for $2 \mathrm{hr}$. After they were washed thoroughly with PB, each sample was immersed in 2.3 m sucrose with $20 \%$ polyvinyl pyrrhoridon and then frozen with liquid nitrogen, as described elsewhere (Waguri et al., 1995).

Ordinal electron microscopy. For light microscopic observations, semithin sections were cut at $1 \mu \mathrm{m}$ with an ultramicrotome (Reichert Ultracut, Nissei, Japan) and stained with toluidine blue. For electron microscopy, silver sections were cut with the ultramicrotome, stained with lead citrate and uranyl acetate, and observed with a Hitachi H-7100 electron microscope.

Detection of autofluorescence. To observe the autofluorescence of lipofuscin granules, deparaffinized sections from each sample were directly viewed with a confocal laser scanning microscope (LSM-GB 200, Olympus, Tokyo, Japan).

Immunohistochemistry for light microscopy. Deparaffinized sections from each sample were immunostained according to the method of Nitatori et al. (1995). Briefly, the samples were treated with $0.3 \% \mathrm{H}_{2} \mathrm{O}_{2}$ in methanol for $30 \mathrm{~min}$ and incubated with $2 \%$ normal goat serum for $20 \mathrm{~min}$ at room temperature. After this, they were incubated at $4^{\circ} \mathrm{C}$ with the following first polyclonal antibodies for 1-3 d: anti-cathepsin B $(2 \mu \mathrm{g} / \mathrm{ml})$, anti-cathepsin $\mathrm{L}(2 \mu \mathrm{g} / \mathrm{ml})$, anti-cathepsin D $(10 \mu \mathrm{g} / \mathrm{ml})$, anti-subunit c $(10 \mu \mathrm{g} / \mathrm{ml})$, and anti-subunit $\beta(10 \mu \mathrm{g} / \mathrm{ml})$. Further incubations were performed with biotinylated goat anti-rabbit IgG for polyclonal antibodies, and peroxidaseconjugated streptavidin (Vectastain ABC Kit, Vector Laboratories, Burlingame, CA) for $1 \mathrm{hr}$ at room temperature. After each step, sections were rinsed thoroughly in $0.1 \mathrm{M}$ phosphate buffered $0.5 \mathrm{M}$ saline (PBS), $\mathrm{pH} 7.2$ containing $0.1 \%$ Tween 20 (Sigma, St. Louis, MO). Staining for peroxidase was performed using $0.0125 \% 3,3^{\prime}$-diaminobenzidine tetrahydrochloride and $0.002 \% \mathrm{H}_{2} \mathrm{O}_{2}$ in $0.05 \mathrm{M}$ Tris- $\mathrm{HCl}$ buffer, $\mathrm{pH} 7.6$, for $10 \mathrm{~min}$.

Immunoelectron microscopy. Ultrathin sections were cut with a microtome using a cryo-attachment (OmU4, Reichert, Vienna, Austria) and mounted on Formvar carbon-coated nickel grids. The sections were rinsed with PBS, treated with $1 \%$ bovine serum albumin (BSA) in PBS, and incubated overnight with anti-cathepsin B $(2 \mu \mathrm{g} / \mathrm{ml})$ or anti-subunit c (10 $\mu \mathrm{g} / \mathrm{ml}$ ) in PBS and for $1 \mathrm{hr}$ with anti-goat IgG conjugated with 5,10 , or 15 nm colloidal gold particles. For double immunostaining, cryothin sections processed for first labeling were treated with $1 \%$ glutaraldehyde in PBS for $10 \mathrm{~min}, 0.01 \mathrm{M}$ glycine in PBS, and then rinsed in $1 \%$ BSA in PBS. They were then processed for second labeling. Immunostained sections were again fixed with $2 \%$ glutaraldehyde in PBS and stained with $1 \%$ uranyl acetate. To distinguish gold labeling, 5 and $15 \mathrm{~nm}$ colloidal gold particles were used, respectively. After the immunoreactions, the sections were embedded in $2 \%$ methyl cellulose containing $0.4 \%$ uranyl acetate and observed with a Hitachi H-7100 electron microscope.

For control experiments, deparaffinized and ultrathin sections were incubated with the nonimmunized rabbit serum diluted to $1: 1000$, followed by respective second antibodies. Some sections were directly incubated with the second antibodies without pretreatments with the first antibodies.

\section{Electrophysiological analysis using a hippocampal slice system}

Hippocampal slices were prepared by the method reported previously (Nakanishi et al., 1996). Briefly, CD-/- mice and control littermates at $\mathrm{P} 11, \mathrm{P} 18$, and P23 were decapitated under light ether anesthesia, and the brains were rapidly removed and placed in an ice-cold oxygenated Krebs' Ringer's solution of the following composition (in mM): NaCl 124.0, KCl 5.0, $\mathrm{KH}_{2} \mathrm{PO}_{4} 1.24, \mathrm{NaHCO}_{3} 26.0, \mathrm{CaCl}_{2} 2.4, \mathrm{MgSO}_{4} 1.3$, and glucose 10. Transverse hippocampal slices with a thickness of $400 \mu \mathrm{m}$ were cut with a Vibratome (Vibroslice 752M, Campden Instruments). A single hippocampal slice was placed in an interface-type recording chamber at a constant bath temperature of $36^{\circ} \mathrm{C}$. Extracellular field potentials were recorded using glass electrodes filled with the perfusate and placed on the stratum pyramidale of the CA1 or the CA3 regions. Electrical responses were stored with a videocassette recorder using a PCM converting system (Stimulating Digital Data Recorder VR-10B, Instrutech Corporation) and plotted on an X-Y plotter.

\section{Enzyme assay}

Brain samples were obtained from $\mathrm{CD}-/-$ mice and their littermate controls at P17, P21, and P23 after the mice were anesthetized with pentobarbital and were independently homogenized with a Politoron homogenizer in a lysate buffer consisting of $0.05 \mathrm{M}$ Tris- $\mathrm{HCl}, \mathrm{pH} 7.5,0.15 \mathrm{M}$ $\mathrm{NaCl}$, and $1 \%$ Triton X-100 for $30 \mathrm{~min}$ on ice. For the measurement of cathepsins B and L activities, the lysates were then diluted with a standard buffer consisting of $0.4 \mathrm{M}$ sodium acetate buffer, $\mathrm{pH} 5.5$, containing $4 \mathrm{~mm}$ EDTA. After centrifugation at $1250 \times g$ for $20 \mathrm{~min}$, the activities of cathepsins $\mathrm{B}$ and $\mathrm{L}$ in each sample extract were assayed using Z-Arg-ArgMCA and Z-Phe-Arg-MCA (Peptide Research Foundation, Osaka, Japan), respectively, as substrates, according to the methods of Barrett and Kirsche (1981). Z-Phe-Arg-MCA used for the assay of cathepsin L is also susceptible to cathepsin B. To measure the specific activity of cathepsin L, a selective inhibitor of cathepsin B, CA074, was applied to the assay system of cathepsin L (Murata et al., 1991; Towatari et al., 1991). We also measured the activity of TPP-I in the brain extracts of both CD-/- and control littermate mice at P23. For this, fluorometric assay of TPP-I using Ala-Ala-Phe-MCA as a substrate was performed as described previously (Page et al., 1993).

\section{Western blotting analysis}

Anesthetized $\mathrm{CD}-/-$ and $\mathrm{CD}+/-$ littermates were decapitated at P17 and $\mathrm{P} 23$, and brain, liver, heart, and kidney samples from each mouse were independently homogenized in $2 \mathrm{ml}$ of $0.05 \mathrm{M}$ Tris-buffered $0.15 \mathrm{M}$ saline containing $1 \%$ Triton X-100 and a protease inhibitor mixture (Boehringer Mannheim, Indianapolis, IN) using a Politron homogenizer at $80 \%$ of the maximal speed. After being centrifuged twice at $10,500 \times g$ for $10 \mathrm{~min}$ at $4^{\circ} \mathrm{C}$, the supernatants were measured for protein concentrations using the BCA protein assay system (Pierce, IL), and immunoblotting was performed. For the detection of subunit c, each sample was separated by tricine SDS-PAGE (Schägger and von Jagow, 1987) in 16.5\% (w/v) acrylamide, whereas other proteins were analyzed by $10 \%$ SDS-PAGE. Electrophoretic transfer of proteins from polyacrylamide gels to a polyvinyli-

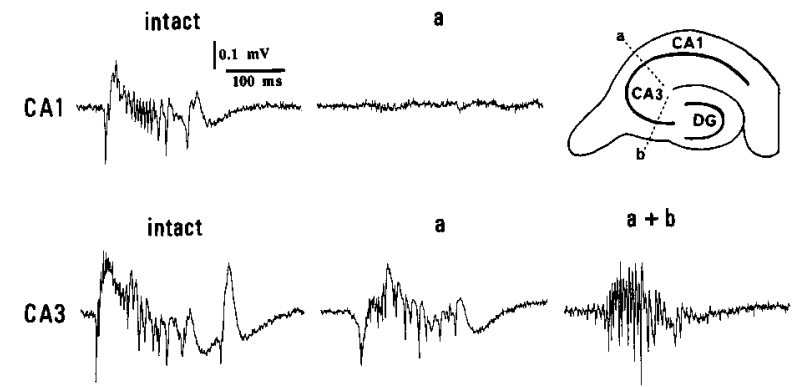

Figure 1. Extracellular recordings obtained from the CA1 and CA3 regions of hippocampal slices obtained from a cathepsin D-deficient mouse at P18. intact, Control recordings; $a$, recordings after cutting the connection between the CA1 and the CA 3 subfields; $a+b$, recordings after an additional cutting of the connection between the CA1 and the dentate gyrus $(D G)$. In situations of $a$ and $a+b$, spontaneous burst discharges were detected in the CA3 region. 

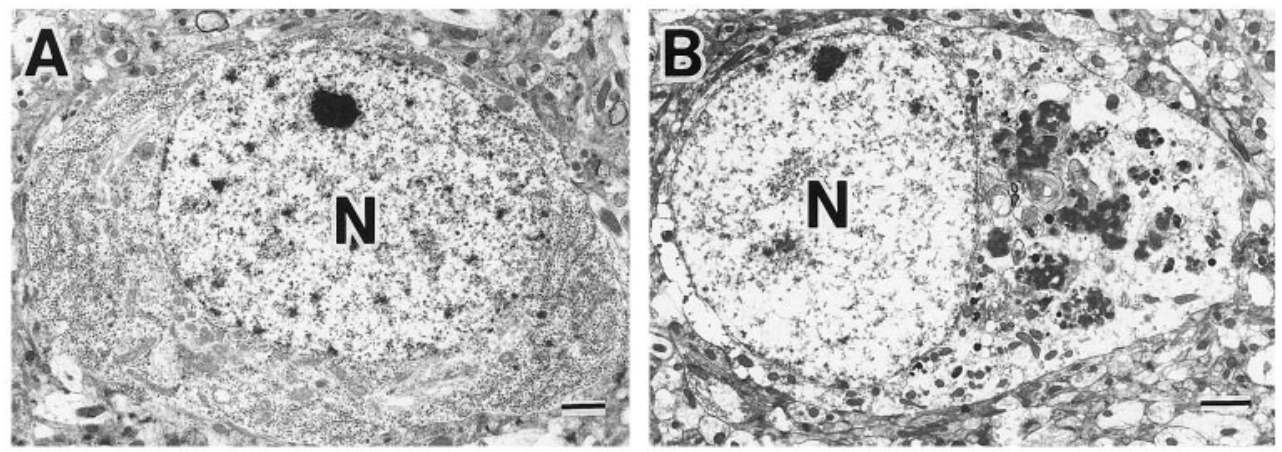

Figure 2. Electron micrographs of autophagosome/autolysosome-like bodies in the neuronal perikarya. $A$, A cerebral cortex neuron obtained from a control littermate mouse at P23. B, C, A cerebral cortex neuron obtained from a cathepsin Ddeficient mouse at P23. A low-power view clearly shows the presence of numerous autophagosome/autolysosome-like bodies in the neuronal perikarya $(B)$, and a highpower view demonstrates the bodies containing granular osmiophilic deposits $(G O)$ and a part of the cytoplasm with or without fingerprint-like myelin figures $(A P)(C)$. The arrow indicates a body with part of the cytoplasm, which is encircled by doublelayered membranes resembling the endoplasmic reticulum. $D$, A fingerprint profile appears in the neuronal perikaryon of a Purkinje cell $(D)$. E, Neuronal cell bodies in the CA3 region of the hippocampus obtained from a cathepsin D-deficient mouse brain at P25. The neuronal cell perikarya are completely filled with membranebounded compartments having dense amorphous materials, part of the cytoplasm, and fingerprint-like myelin figures $(M F)$. A neuronal cell is seen, possessing a shrunken nucleus with small chromatin masses dispersed in the karyoplasm and is encircled with cytoplasmic processes (arrowheads) of a microglial cell $(M) . F, G$, Appearance of dense granular deposits in the perikarya of CA3 pyramidal neurons in the hippocampus obtained from cathepsin D-deficient mice at $\mathrm{P} 1(F)$ and $\mathrm{P} 17$ $(G)$. The dense granular bodies (arrows) appear in the neuronal perikarya at P1 but are fewer in number, whereas they increase in number at P17. The matrix of the bodies is similar to those seen after P20 $(C)$, except for fingerprint-like figures, which are rarely detectable at $\mathrm{P} 1 . N$, Nucleus. Scale bars: $A, B, E, F, G, 1.5 \mu \mathrm{m} ; C, D, 0.25 \mu \mathrm{m}$.
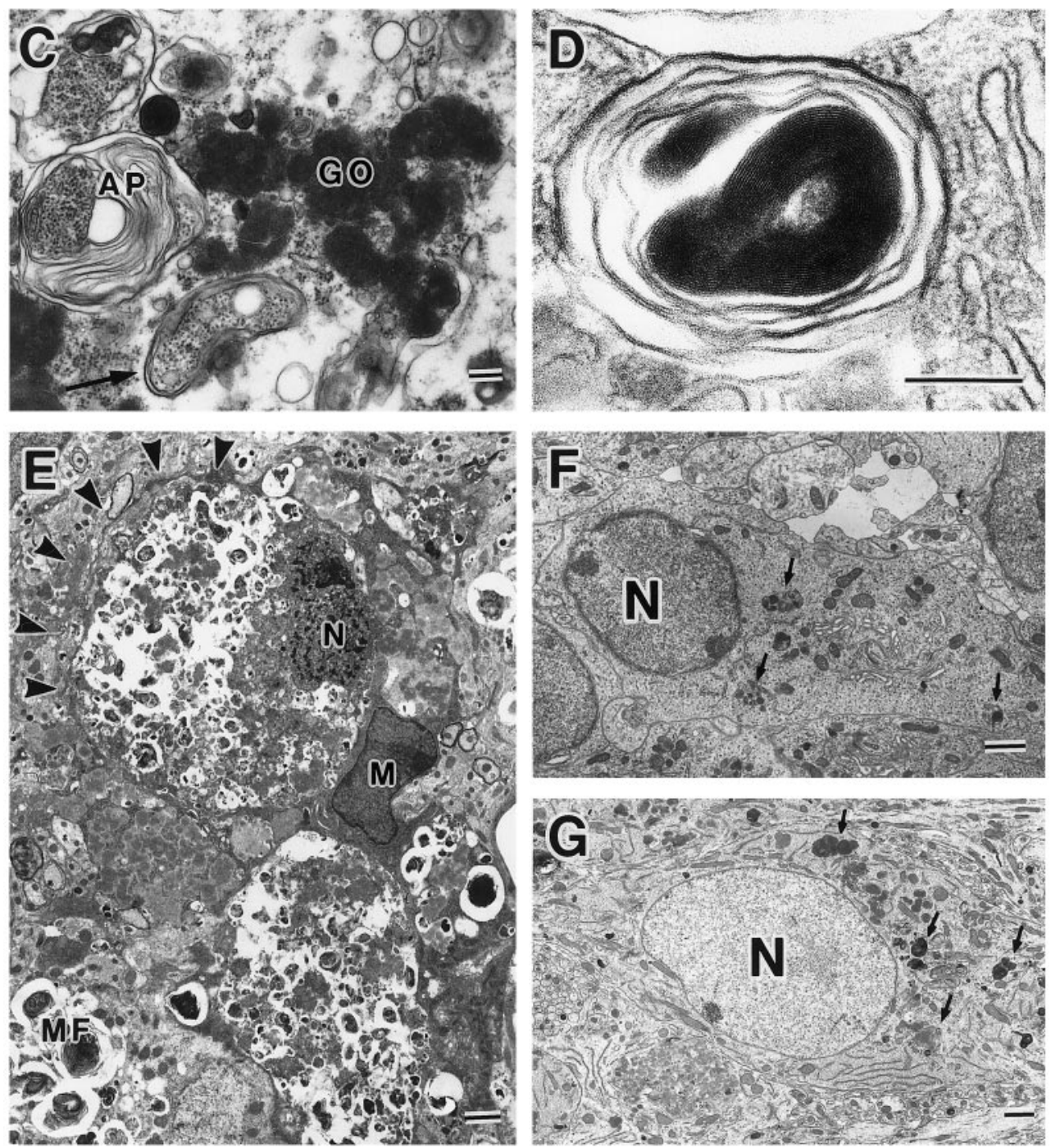

dene difluoride membrane (Immobilon-P, Millipore, Tokyo, Japan) was performed according to the method of Towbin et al. (1979). The sheets were soaked in PBS containing 5\% BSA (Sigma) to block nonspecific binding and then incubated with antisera. Immunodetection was performed with a chemiluminescent ECL kit (Amersham, Arlington Heights, IL) according to the manufacturer's recommended protocol. Protein levels were determined by scanning densitometry.

\section{RESULTS}

\section{Neurological manifestations}

CD $-/-$ mice usually grow normally for up to 2 weeks of age and then cease to grow and die at P26 \pm 1 as the result of intestinal necrosis and a reduced feeding behavior (Saftig et al., 1995). However, in our study, they sometimes died without showing any necrotic changes in the small intestine. In any case, the mice began to manifest repetitive seizures from approximately P20; they began to tremble and move on their tiptoes with a stiff tail. In some cases they suffered from severe tonic seizures and died as a result of respiratory arrest. Moreover, the eyelids of the $\mathrm{CD}-/-$ mice were found to be almost closed near the terminal stage. We therefore examined the issue of whether these mice were blind on P23, using a box that contained light and dark regions separated by a dark curtain. As far as could be determined, all $15 \mathrm{CD}-/-$ mice that had been placed in the light region did not move into the dark region, whereas all of the control littermate mice moved into the dark region. This suggests that the $\mathrm{CD}-/-$ mice were unable to react to the light because they were blind. When the CNSs of the knockout mice were compared with the littermate controls on P23, the brains appeared to be similar in size. 


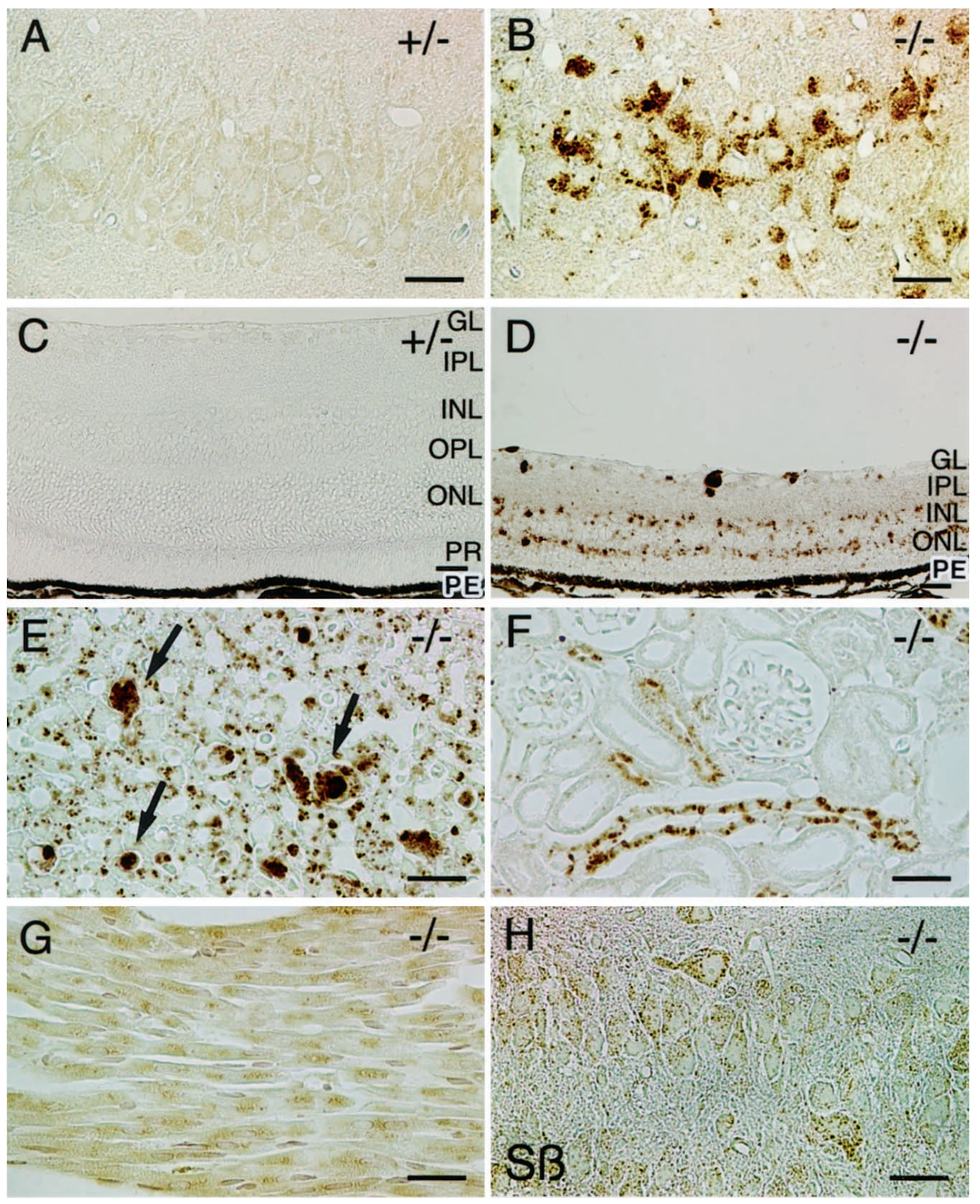

Figure 3. Immunostaining for subunits $\mathrm{c}$ and $\beta(S \beta)$ of mitochondrial F1F0ATPase at P23. $A-D$, Immunoreactivity for subunit $\mathrm{c}$ is large-granular and intensely localized to neuronal perikarya in the CA1 layer $(B)$ and the outer and inner nuclear (granular) layers $(O N L$ and $I N L)$ and ganglion cells $(G L)$ of the retina $(D)$ in the $\mathrm{CD}-/-$ mouse $(-/-)$, whereas no immunoreactivity is detected in the same regions of the control $(+/-)(A, C) \cdot E-G$, Positive staining of subunit $\mathrm{c}$ is large-granular in Kupffer cells (arrows) and fine-granular in hepatocytes $(E)$. Immunodeposits for subunit c are present in epithelial cells of renal tubules $(F)$ and cardiac muscular cells $(G)$. Finegranular immunoreactivity for subunit $\beta$ is clearly localized to the CA1 neuronal cell bodies $(H)$. Scale bars, $20 \mu \mathrm{m}$.

\section{Electrophysiological analysis of hippocampal slices}

To examine repetitive seizures from approximately P20, electrophysiological analysis of hippocampal neurons was performed using slices. In hippocampal slices prepared from $\mathrm{CD}-/-$ mice after P18, spontaneous burst discharges consisting of 4-15 population spikes superimposed on a prolonged positive deflection (60-150 msec) were recorded from the stratum pyramidale of both the CA1 and the CA3 regions (Fig. 1). These spontaneous burst discharges recorded from the regions were well synchronized, indicating the epileptiform nature of the bursting. The mean frequency of spontaneous burst discharges recorded from hippocampal slices obtained from $\mathrm{CD}-/-$ mice at $\mathrm{P} 18$ and $\mathrm{P} 23$ was $0.15 \mathrm{~Hz}(n=3)$ and $0.25 \mathrm{~Hz}(n=2)$, respectively. On the other hand, no spontaneous activity was recorded from hippocampal slices obtained from control littermates even at P23 (data not shown).

When a surgical cut was performed between the CA1 and CA3 sectors, spontaneous burst discharges in the CA3 sector were unaffected, but those in the CA1 sector were abolished (Fig. 1, $a$ ), indicating that spontaneous burst discharges in the CA1 region were driven by burstings in the CA3 region. Burst discharges in the CA3 region still remained after an additional cut was made between the CA3 region and the dentate gyrus (Fig. 1, $a+b$ ).

\section{Accumulation of autophagosomes/autolysosomes in neurons}

In semithin sections, large neurons in various CNS regions such as the cerebral cortex, cerebellar cortex, and spinal anterior horn, and in the retina at $\mathrm{P} 23$, possessed numerous inclusions in their perikarya (data not shown). We therefore examined large neurons in various CNS regions by electron microscopy. Different from neurons in the littermate control brains at the corresponding stages (Fig. 2A), neurons in $\mathrm{CD}-/-$ mouse brains after $\mathrm{P} 20$ possessed numerous granular structures, which varied in size, content, and electron density, in the perikarya (Fig. $2 B, C$ ). In particular, near the terminal stage (P23-P26) the neurons were completely filled with these granules; they were encircled by the limiting membrane, containing part of the cytoplasm and granular osmiophilic deposits (Fig. 2B,C). Some of these structures were surrounded by doublelayered membranes resembling the endoplasmic reticulum, indicating that they were autophagosomes or autolysosomes. Fingerprint profiles also appeared in neuronal cell bodies (Fig. 2D) and retinal pigment cells (data not shown). Most neurons having such autophagosome/autolysosome-like bodies had large nuclei with one or two nucleoli. However, neurons that were shrunken and possessed irregularly shaped nuclei with small dense chromatin dis- 


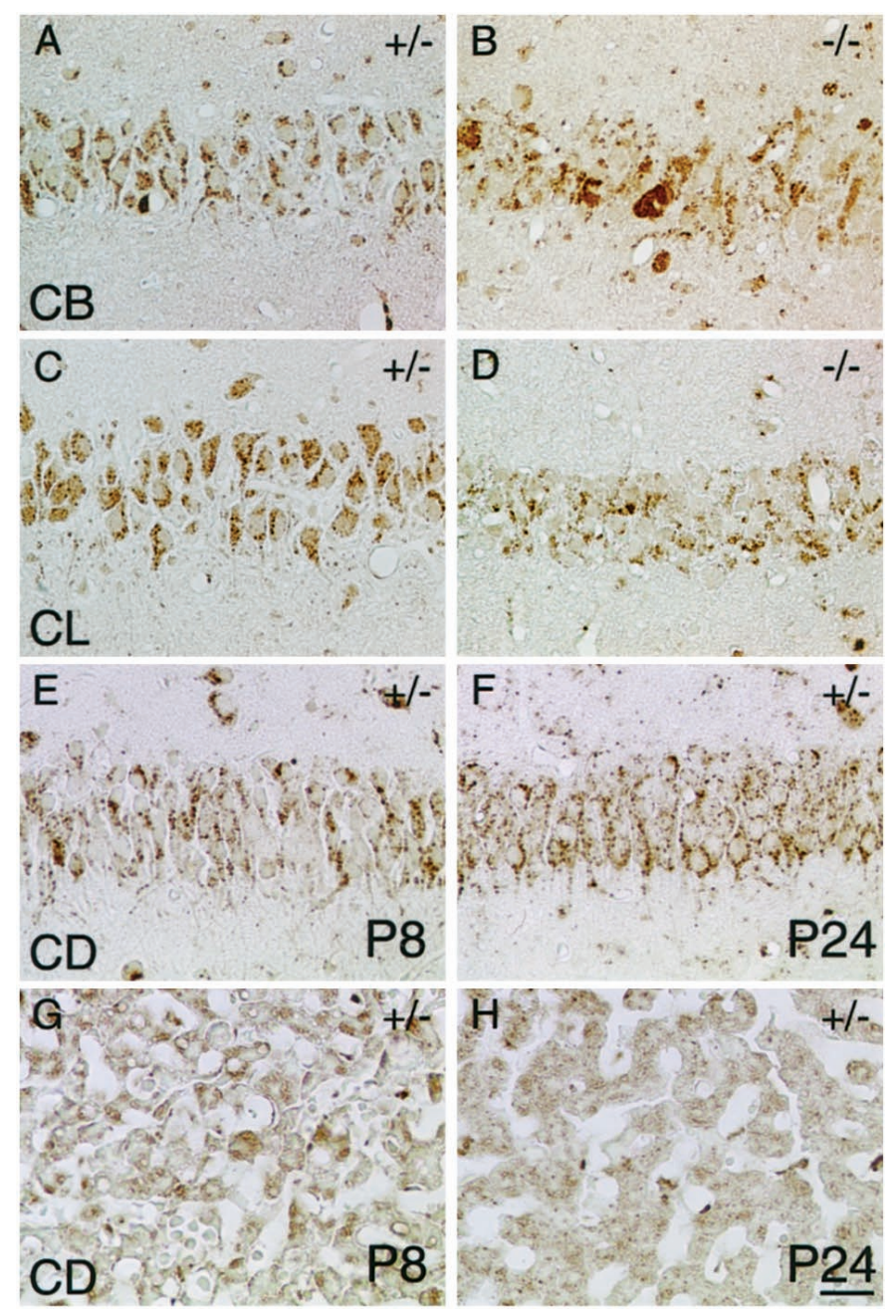

Figure 4. Immunohistochemical demonstration of cathepsin $\mathrm{B}(C B)$, cathepsin $\mathrm{L}(C L)$, and cathepsin $\mathrm{D}(C D)$ in various tissue cells. $A-D$, Immunostaining of cathepsins $\mathrm{B}$ and $\mathrm{L}$ in $\mathrm{CA} 1$ pyramidal layers of control littermate $(+/-)$ and cathepsin D-deficient $(-/-)$ mice at P26. $A, B$, Fine-granular immunodeposits for cathepsin $\mathrm{B}$ are well localized to the perikarya of $+/-$ pyramidal neurons $(A)$, whereas the immunodeposits are coarse and in some cases large-granular in the perikarya of $-/-$ neurons $(B) . C, D$, No clear-cut difference is detected in the immunoreactivity for cathepsin L between pyramidal neurons obtained from control and knockout mice. $E-H$, Immunostaining of cathepsin D in CA1 pyramidal layers $(E$, $F)$ and liver tissues $(G, H)$ obtained from the control CD $+/-$ mice at P8 $(E, G)$ and P24 $(F, H)$. Immunodeposits for cathepsin D are distinct in both tissue cells at each stage, and no clear-cut differences are detected in distribution patterns in these tissues between the two stages, respectively. Scale bar, $20 \mu \mathrm{m}$.

persed in the nucleoplasm appeared in the pyramidal layers of the cerebral cortex and the CA3 region of the hippocampus and the thalamic region at the terminal stage (Fig. $2 E$ ). These cells were often encircled by cytoplasmic processes of microglia-like cells.

We next determined when these autophagosome/autolysosomelike bodies appear in the neurons of the cerebral cortex and hippocampus in $\mathrm{CD}-/-$ mice. Autophagic bodies possessing part of the cytoplasm and dense granular deposits were discernible in neurons even at P1 but were very small in number (Fig. $2 F$ ). At P7 and P14, these autophagosome/autolysosome-like bodies increased in number in the neuronal perikarya, compared with those at P1. Until P14, the organization of the cytoplasmic organelles and nuclei in neuronal cell bodies appeared intact, although the cells possessed certain numbers of autophagosome/autolysosome-like bodies. These bodies further increased in number and were scattered throughout the neuronal perikarya at P17, although their number was still smaller than that appearing in nerve cells after P20 (Fig. 2G). Autophagosome/autolysosome-like bodies with fingerprint-like figures appeared to be small in number in neurons until P17.

\section{Lysosomal accumulation of subunit $\mathrm{c}$ of mitochondrial F1F0ATPase}

In addition to characteristic morphological features of lysosomelike structures, such as the presence of part of the cytoplasm, granular osmiophilic deposits, and fingerprint profiles in neuronal cell bodies, we confirmed that these neurons emitted autofluorescence especially from P17 (data not shown). Because these data are consistent with the lysosome-like bodies containing ceroid lipof uscin, we further examined whether subunit $\mathrm{c}$ of mitochondrial F1F0ATPase is present in these lysosomal structures. No immunoreactivity for subunit $\mathrm{c}$ was detected in any of the brain sections obtained from the control littermates examined (Fig. $3 A$ ). On the contrary, dotted immunoreactivity for subunit c was already detectable in neuronal cell bodies located in limited areas of $\mathrm{CD}-/-$ mouse brains at P1 but appeared very small in number. The immunoreactivity for subunit c became distinct in neurons 2 weeks after birth, and immunodeposits were abundantly seen as coarse granules after P20, especially at P23 (Fig. $3 B$ ). In the retina of $\mathrm{CD}-/-$ mice, subunit c-immunopositive granules were distinct in the outer and inner granular and ganglion cell layers (Fig. 3C,D). Moreover, the retinal layers of $\mathrm{CD}-/-$ mice became thinner than those of the control littermates; particularly, the cone and rod layer was almost abolished, and the outer granular layer became much thinner (Fig. 3C,D).

To examine whether the accumulation of subunit $\mathrm{c}$ occurs in peripheral tissues, immunohistochemistry was applied to liver, kidney, and cardiac tissues. Positive staining of subunit c was intensely detected in the liver; the immunodeposits were largegranular in Kupffer cells, whereas they were fine-granular in hepatocytes (Fig. 3E). Subunit c-immunopositive granules were also seen in epithelial cells of renal tubules and cardiac muscular cells (Fig. $3 F, G$ ). These results indicate that the accumulation of subunit c occurs systemically in CNS tissues as well as in peripheral body tissues.

Similar to the immunoreactivity for subunit $\mathrm{c}$, that for subunit $\beta$ of mitochondrial ATP synthase was not usually detectable throughout the CNS tissues of the control mice (data not shown). However, immunodeposits for subunit $\beta$ appeared in neuronal cell bodies of $\mathrm{CD}-/-$ mouse brains at $\mathrm{P} 23$, but they were fewer in number and much finer than the subunit c-immunopositive structures (Fig. $3 H$ ).

Because subunit c was immunohistochemically detected as coarse granules in the neuronal perikarya of $\mathrm{CD}-/-$ mouse brains, we further examined its association with lysosomes using light and electron microscopic immunocytochemistry. As shown in Figure 4, $A$ and $B$, the distribution pattern of cathepsin B, a lysosomal cysteine proteinase, was similar to that of subunit $\mathrm{c}$ in neuronal cell bodies of $\mathrm{CD}-/-$ mouse brains after P20, especially at P26, and its immunoreactivity was more intense in neurons of $\mathrm{CD}-/-$ mouse brains than in those of the controls. However, when lysosomes were immunostained for cathepsin L, which is also a lysosomal cysteine proteinase, its immunoreactivity did not differ between neurons of the $\mathrm{CD}-/-$ and control mouse brains, although it was coarse, similar to that of subunit $\mathrm{c}$ in neurons of $\mathrm{CD}-/-$ mouse brains (Fig. $4 C, D)$.

Moreover, because the accumulation of lysosomal bodies in CNS and peripheral tissue cells rapidly proceeded after P17, we also examined whether the lysosomal distribution of $\mathrm{CD}$ varies in $\mathrm{CNS}$ neurons and liver cells of control $\mathrm{CD}+/-$ mice before and after P17. Immunodeposits for cathepsin D were fine-granular and densely distributed in the neurons of the hippocampus and in hepatocytes of the CD+/- mice at P1, P8, P14, P17, P24, and P26, whereas distribution patterns of the immunoreactivity did not differ in these tissue between P8 and P24, respectively (Fig. 4E-H).

To reveal the subcellular localization of subunit $\mathrm{c}$ in large neurons of the cerebral cortex from $\mathrm{CD}-/-$ and control littermate mice at P23, immunoelectron microscopy using the cryothin section immunogold method was applied to the tissues. Immunogold par- 

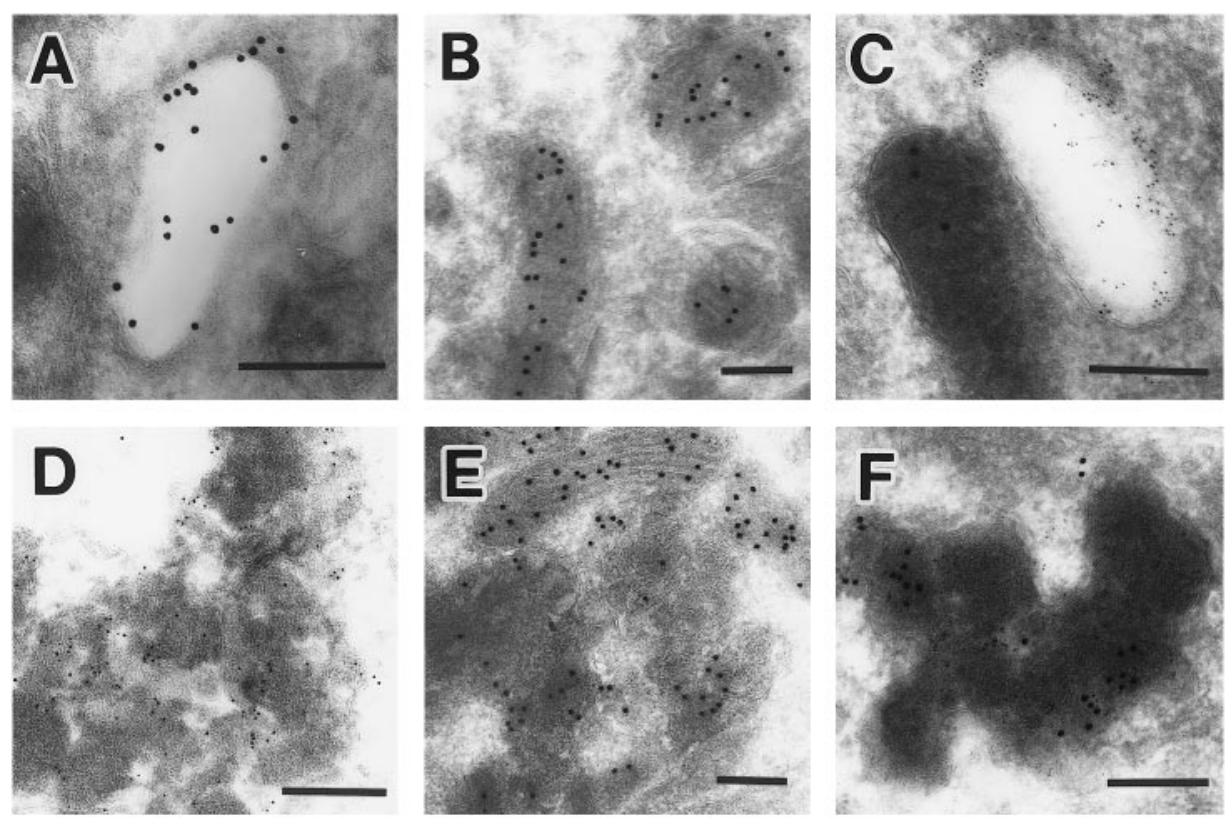

Figure 5. Immunocytochemical staining of cathepsin B and subunit $\mathrm{c}$ of mitochondrial F1F0ATPase in neuronal cell bodies of the cerebral cortex from cathepsin D-deficient $(D-F)$ and control littermate $(A-C)$ mice at P23, using the cryothin section immunogold method. $A, D$, Cathepsin B. Gold labeling is clearly localized to electron-lucent lysosomes in the control $(A)$, whereas it is detected in membrane-bound compartments with electrondense materials in a deficient mouse $(D) . B, E$, Subunit c. Gold particles label only the mitochondrial inner membrane in the control mouse $(B)$, whereas they are associated with both the inner membrane of intact mitochondria and the membrane-bound compartments with dense materials in the knockout mouse $(E)$. $C, F$, Double immunostaining of cathepsin B (gold particles, $5 \mathrm{~nm}$ in diameter) and subunit c (gold particles, $15 \mathrm{~nm}$ in diameter). In the control, small gold particles for cathepsin B clearly label an electron-lucent lysosome, whereas large particles for subunit $\mathrm{c}$ are localized to the mitochondrial inner membrane $(C)$. In the deficient mouse, small and large gold particles are colocalized in electron-dense compartments $(F)$. Scale bars, $0.25 \mu \mathrm{m}$. ticles indicating cathepsin B labeled membrane-bound lysosomes with an electron-lucent matrix in the neuronal perikarya of controls (Fig. 5A). In CD-/- mouse neuronal cell bodies, the labeling was also associated with irregularly shaped and membrane-bound structures containing electron-dense materials (Fig. 5D), characterizing them as lysosomes. In the neurons of controls, subunit $\mathrm{c}$ was detectable by immunogold labeling in the mitochondrial inner membrane (Fig. $5 B$ ). In neurons from $\mathrm{CD}-/-$ mice, the labeling for subunit $\mathrm{c}$ was also associated with membrane-bound structures containing electron-dense materials (Fig. 5E). By double staining, the structures with dense materials in $\mathrm{CD}-/-$ mouse neurons at P23 were colabeled with immunogold particles showing both cathepsin $\mathrm{B}$ and subunit $\mathrm{c}$ (Fig. $5 F$ ), demonstrating the lysosomal accumulation of subunit $\mathrm{c}$. In the littermate controls, subunit $\mathrm{c}$ was only detected in the inner membrane of mitochondria, and cathep$\sin \mathrm{B}$ was detected in the electron-lucent lysosomes (Fig. 5C).

\section{Biochemical analyses of lysosomal proteinases and storage proteins}

To confirm immunohistochemical and cytochemical results, we measured proteolytic activities of lysosomal cathepsins B and L and concentrations of lysosomal and mitochondrial proteins in extracts from $\mathrm{CD}-/-$ and $\mathrm{CD}+/-$ mouse brains. The proteolytic activity of cathepsin B was increased in the brain extracts of CD-/- mice at P23, compared with that in control littermates, although the difference in the activity was small and not significant at P17 and P21 between the two groups (Fig. 6A). Different from cathepsin B, the proteolytic activity of cathepsin L showed no changes in the brain extracts obtained from control and $\mathrm{CD}-/-$ mice at $\mathrm{P} 17, \mathrm{P} 21$, and $\mathrm{P} 23$, respectively (Fig. $6 A$ ). Corresponding to the changes in proteolytic activity of cathepsin $\mathrm{B}$, the frequency of cathepsin $\mathrm{B}$ polypeptides was similar in brain extracts obtained from control and $\mathrm{CD}-/-$ mice at $\mathrm{P} 17$, whereas it was clearly increased in CD $-/-$ mice at P23 (Fig. $6 B, C$ ). The frequency of cathepsin $\mathrm{L}$ polypeptides in $\mathrm{CD}-/-$ mice and control littermates on P17 and P23 was comparable (Fig. 6B,C). Subunit c was clearly more concentrated in the extracts from $\mathrm{CD}-/-$ mouse brains at $\mathrm{P} 23$, but a moderate increase was already evident at P17 (Fig. 6B,C). Different from immunocytochemistry, no increase of subunit $\beta$ was detectable in the brain extracts from $\mathrm{CD}-/-$ mice at P17 and P23 (Fig. 6B,C). Because subunit $\mathrm{c}$ accumulated in lysosomes of $\mathrm{CD}-/-$ neurons, we examined the issue of whether the activity of TPP-I, which cleaves the N-terminal portion of subunit c, is suppressed in extracts from $\mathrm{CD}-/-$ mouse brains at $\mathrm{P} 23$. As shown in Figure $6 D$, the activity of TPP-I was significantly higher in CD-/- than in control brains. Its protein level in the $\mathrm{CD}-/-$ brains was also increased, compared with that in the control brains (Fig. $6 E, F)$.

Because immunodeposits for subunit c were positive in liver, kidney, and heart tissues of $\mathrm{CD}-/-$ mice, we also examined differences in the amounts of subunit $c$ in these tissue extracts by immunoblotting. Concentrations of subunit $\mathrm{c}$ were distinctly elevated in extracts of these tissues obtained from $\mathrm{CD}-/-$ mice at P23, compared with those from control littermate mice (Fig. $6 G, H)$.

\section{DISCUSSION}

The present morphological and immunochemical studies on CNS tissues of $\mathrm{CD}-/-$ mice obtained after P20 demonstrated that the mice manifested seizures with trembling and stiff tails and blindness, that the large neuronal cell bodies in various CNS regions including the retina accumulated autophagosomes/autolysosomes or ceroid lipofuscin granules containing part of the cytoplasm, granular osmiophilic deposits, and fingerprint profiles, that neuronal cell bodies were immunopositive for subunit $\mathrm{c}$ of mitochondrial F1F0ATPase, and that protein levels of subunit c were clearly increased, whereas the activity and protein levels of TPP-I were augmented. The accumulation of subunit $\mathrm{c}$ was also detected in peripheral tissues such as the liver, kidney, and heart.

The present electron microscopic study revealed that the accumulation of membrane-bound compartments containing part of the cytoplasm, granular osmiophilic deposits, and fingerprint profiles occurs in the perikarya of most neurons in $\mathrm{CD}-/-$ mouse brains near the terminal stage. Double-layered membranes resembling the endoplasmic reticulum occasionally encircled part of the cytoplasm in the perikarya of neuronal cell bodies, indicating that they are in the process of sequestration by macroautophagy (Holtzman, 1989). Moreover, they emitted autofluorescence and were immunopositive for cathepsin B and subunit c. These features indicate that the granular structures accumulating in neuronal cell bodies of $\mathrm{CD}-/-$ mouse brains are autophagosomes/autolysosomes containing ceroid lipofuscin.

The accumulation of ceroid lipofuscin granules in neurons is seen in a spectrum of diseases and during aging (Elleder et al., 1997; Nakanishi et al., 1997) and can be pharmacologically induced by intraventricular application of leupeptin, an inhibitor of lysosomal cysteine proteinases, or of chloroquine, an acidotropic agent that accumulates in lysosomes and blocks protein degradation (Ivy et al., 1984; Ivy, 1992). The morphological features of ceroid 
Figure 6. Biochemical analyses of lysosomal proteinases and storage proteins in $\mathrm{CD}-/-$ mouse brains. $A$, Proteolytic activity of cathepsins B (left) and cathepsin L (right) in brain extracts from cathepsin D-deficient $(-/-)$ and control littermate $(+/-)$ mice at P17, $\mathrm{P} 21$, and P23. The cathepsin B activity is significantly increased in knockout mouse brains at P23, compared with that in the control, whereas the differences in the activity are not significant at P17 and P21 between the two groups, respectively. No clear-cut difference is detected in the cathepsin L activity between the $-/-$ and $+/-$ brains on P17, $\mathrm{P} 21$, and P23. The activity was expressed as nanomole per minute per milligram of protein $(n=3$ in each case). $B$, Immunoblot analyses of cathepsins $\mathrm{B}(C B)$ and $\mathrm{L}(C L)$ and subunits c $(S c)$ and $\beta(S \beta)$ from cathepsin D-deficient $(-/-)$ and control littermate $(+/-)$ mouse brains. Immunoreactive bands for cathepsin B (single chain form) are distinctly augmented in the $-1-$ mouse brain at $\mathrm{P} 23$, whereas no difference is seen between the two groups at P17. Protein bands immunostained for cathepsin L (single chain form) show similar densities between $-1-$ and $+1-$ mouse brains at P17 and P23. Immunoreactive bands for subunit $\mathrm{c}$ are much more increased in the $-1-$ mouse brain at P23 than in the $+/-$ mouse brain, whereas no difference is detected in immunoreactive bands for subunit $\beta$ between the two groups at both P17 and $\mathrm{P} 23$. In $B$, protein makers are on the left side. In each lane, $20 \mu \mathrm{g}$ of protein was applied. $C$, Quantification of $B$. The blotted densities of each protein were measured with a Scanning Imager. $D$, The activity of TPP-I in $\mathrm{CD}-1-$ and control littermate brains at P23. The activity was expressed as nanomole per minute per milligram of protein $(n=3$ for each case). $E$, Immunoblot analysis of TPP-I in CD $-/-$ and control littermate mouse brains at P23. Protein maker is on the left side. F, Quantification of $E$. $G$, Immunoblot analysis of subunit $\mathrm{c}$ in extracts of liver, kidney, and heart tissues of $\mathrm{CD}-/-$ and littermate control mice at P23, $H$, Quantification of $G$. The protein amounts applied in $E$ and $G$ and the measurement of protein bands in $F$ and $H$ followed $B$ and $C$, respectively. The density of each protein band in control brain extracts was estimated as $100 \%$.
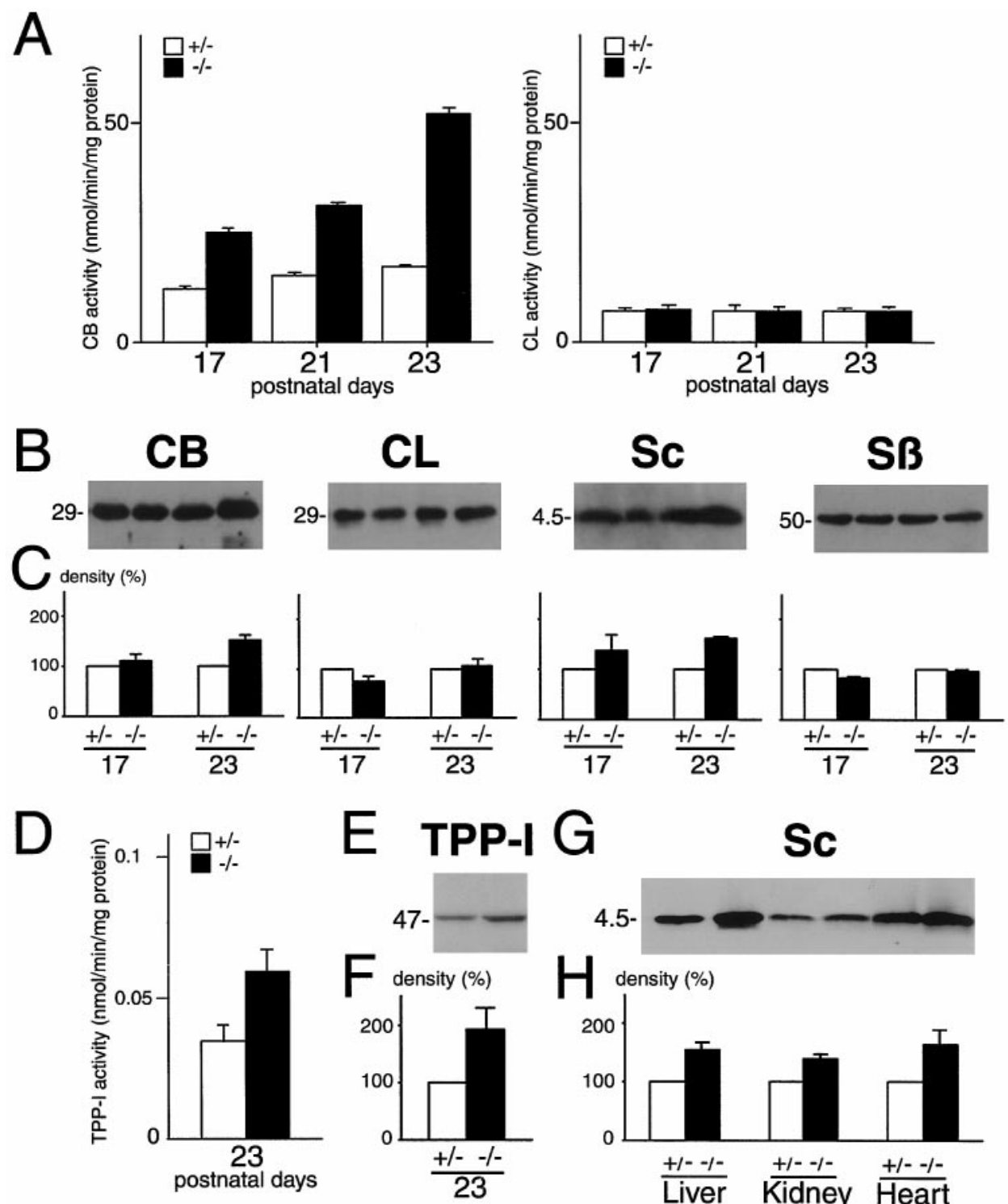

Sc
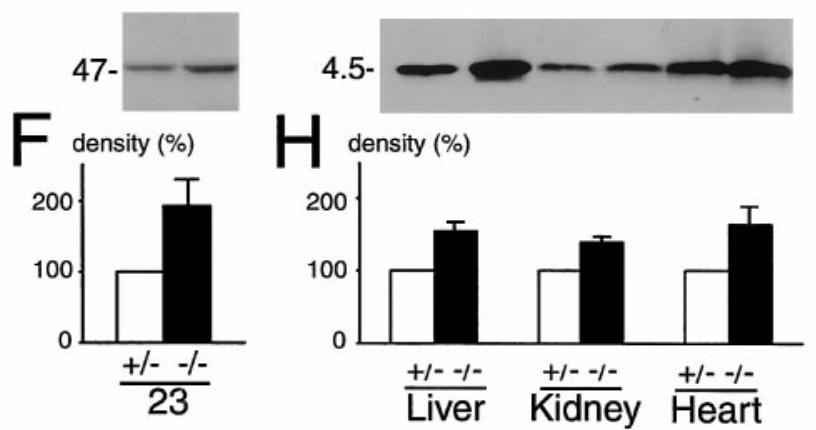

lipof uscin granules induced by leupeptin or chloroquine resemble those seen in $\mathrm{CD}-/-$ mouse brains, but the size and texture of the granules are more variable in the latter. The inhibition of cathepsins B and L, major lysosomal cysteine proteinases, by $N$-CBZ-Lphenylalanyl-L-alanine-diazomethylketone also produces an accumulation of lysosome-related dense bodies in the perikarya of CA1 neurons in cultured hippocampal slices (Bednarski et al., 1997). However, these structures are largely dense bodies that do not emit autofluorescence, suggesting that they do not contain ceroid lipofuscin. From these lines of evidence it is apparent that genetically or pharmacologically induced accumulation of ceroid lipofuscin in $\mathrm{CD}-/-$ neurons is a specific event and does not merely reflect a major block of proteolysis.

The role of $\mathrm{CD}$ in proteolysis in neuronal cells has remained elusive. It is known whether the activity and the amount of CD increase in aged brains and some neurodegenerative diseases (Nakamura et al., 1989; Nixon et al., 1992; Ii et al., 1993; Nakanishi et al., 1994; Cataldo and Nixon, 1995). It has been suggested that it participates in the degradation of various cytoskeletal proteins (Banay-Schwartz et al., 1983, 1987; Matus and Green, 1987; Johnson et al., 1991; Ladror et al., 1994; Mercken et al., 1995). The present study demonstrates that the loss of CD induces the prominent accumulation of ceroid lipofuscin-containing lysosomes, which rapidly proceeded after P17. This strongly suggests that CD plays a critical role in lysosomal proteolysis in CNS neurons after certain postnatal stages. At present, the issue of why the role of CD becomes important after a certain number of postnatal days remains unknown. Considering that $\mathrm{CD}$ was distinctly distributed in CNS neurons and peripheral tissue cells of $\mathrm{CD}+/-$ mice even at P1 (data not shown), the role of CD may be associated with tissue maturation.

One of the most exciting pieces of data in the present study revealed the accumulation of subunit $c$ of mitochondrial F1F0ATPase in autophagosomes/autolysosomes both in CNS neurons and in the peripheral tissue cells of $\mathrm{CD}-/-$ mice. The accumulation of subunit $\mathrm{c}$ coincided well with the appearance of autofluorescence in these tissue cells, indicating that the loss of the $\mathrm{CD}$ generation induces the systemic accumulation of subunit $\mathrm{c} / \mathrm{cer}$ oid lipof uscin-containing lysosomes. A number of diseases show an excessive accumulation of subunit $\mathrm{c}$ in secondary lipopigments of CNS neurons (Elleder et al., 1997). Among these diseases, however, only NCLs, a group of progressive hereditary neurodegenerative diseases, also collectively referred to as Batten disease, are known to accumulate subunit $\mathrm{c}$ in ceroid lipofuscin not only in CNS neurons but also in peripheral tissue cells. The accumulation of subunit $\mathrm{c}$ is most typical in the late onset form of infantile NCLs (Kominami et al., 1992; Elleder et al., 1997).

In fibroblasts obtained from late infantile NCL (CLN2) patients in whom TPP-I (CLN2p), a pepstatin-insensitive proteinase, is absent, Ezaki et al. (1999) have shown that the degradation of 
subunit $\mathrm{c}$ is impaired, suggesting that TPP-I plays a critical role in the degradation of subunit c. The participation of additional proteinases in the degradation of subunit $\mathrm{c}$, however, is suggested by the observation that incubation of fibroblasts in the presence of pepstatin, a potent inhibitor of aspartic proteinases, leads to the lysosomal accumulation of subunit $\mathrm{c}$ but not of subunit $\beta$ (Ezaki et al., 1996). The present study shows that the proteolytic activity and protein levels of TPP-I in CD-/- mouse brains at P23 were significantly increased. The accumulation of subunit $\mathrm{c}$ in $\mathrm{CD}-/-$ cells despite an increased activity of TPP-I as shown for brain clearly indicates that both TPP-I and CD are critical for degradation of subunit $\mathrm{c}$.

It is well known that ultrastructural features of NCLs in CNS neurons are characterized by the appearance of membrane-bound compartments containing granular osmiophilic deposits, curvilinear bodies, and fingerprint profiles (Elleder et al., 1997). Ultrastructural features characteristic of NCLs such as granular osmiophilic deposits and fingerprint profiles were also detected in CNS neurons and retinal pigment cells of $\mathrm{CD}-/-$ mice. Many neurons in the cerebral cortex, hippocampus, and thalamus of $\mathrm{CD}-/-$ mouse brains were eventually engulfed by microglial cells, indicating that they underwent neuronal death. This is consistent with the observation that terminal deoxynucleotidyl transferase-mediated biotinylated dUTP nick end labeling-positive neurons appear in the CNS of NCLs (Lane et al., 1996). The retina in infantile NCL shows a loss of photoreceptor cells, a decrease in the inner granular layer, and a deposition of ceroid lipofuscin in ganglion cells (Goebel et al., 1988). In addition to these changes in retinal layers, the present data that show the deposition of subunit $\mathrm{c}$ in retinal layers of $\mathrm{CD}-/-$ mice and their behavioral change during light stimulation point toward the blindness of the mice. Thus, clinical symptoms of late infantile NCL partly resembled those of CD deficiency in mice. However, lysosomal bodies with granular osmiophilic deposits and autophagosomes predominated in $\mathrm{CD}-/-$ mouse neurons, whereas curvilinear bodies are typical for the morphology of lysosomes appearing in late infantile NCL (Elleder et al., 1997). Moreover, as stated above, the only accumulated substance in lysosomes of late infantile NCL is subunit c, but the amounts of cathepsin B and TPP-I were also increased in the lysosomes of $\mathrm{CD}-/-$ mice in addition to subunit $\mathrm{c}$. These different observations may suggest that $\mathrm{CD}$ deficiency leads to a different subgroup of NCLs.

Older CD $-/-$ mice after P20 manifested seizures, a typical clinical feature of NCLs. We therefore examined electrophysiological features of hippocampal neurons using slices. The hippocampal CA1 and CA3 neurons of the CD-/ - mice after P18 exhibited spontaneous and synchronized burst properties, which were never observed in the control littermates, whereas the burst activity of the hippocampus was initiated in the CA3 region. Within the hippocampus, which has been implicated as being important in epileptogenesis, the CA3 subfield is especially well known for its pacemaker-like activity (Hablitz and Johnston, 1981). These electrophysiological results suggest that the pacemaker-like activity of the CA3 region is responsible for generalized seizures in the $\mathrm{CD}-/-$ mice, although the precise mechanism for the intrinsic burst property of the $\mathrm{CA} 3$ neurons in $\mathrm{CD}-/-$ mice remains unclear.

Collectively, the present data from CD-/- mice showing (1) the manifestation of seizures and blindness, (2) the accumulation of subunit c/ceroid lipof uscin-containing lysosomes in CNS neurons and peripheral tissue cells, and (3) the appearance of granular osmiophilic deposits and fingerprint profiles demonstrate that the loss of the CD generation in mice is associated with the phenotype of neuronal ceroid lipofuscinosis.

\section{REFERENCES}

Banay-Schwartz M, Bracco F, DeGuzman T, Lajtha A (1983) Developmental changes in the breakdown of brain tubulin by cerebral cathepsin D. Neurochem Res 8:51-61.

Banay-Schwartz M, Dahl D, Hui KS, Lajtha A (1987) The breakdown of the individual neurofilament proteins by cathepsin D. Neurochem Res 12:361-367.

Bando Y, Kominami E, Katunuma N (1986) Purification and tissue distribution of rat cathepsin L. J Biochem (Tokyo) 100:35-42.

Barrett AJ, Kirsche H (1981) Cathepsin B, cathepsin H, cathepsin L. Methods Enzymol 80:535-561.

Bednarski E, Ribak CE, Lynch G (1997) Suppression of cathepsins B and $\mathrm{L}$ causes a proliferation of lysosomes and the formation of meganeurites in hippocampus. J Neurosci 17:4006-4021.

Berkovic SF, Carpenter S, Andermann F, Andermann E, Wolfe LS (1988) Kufs' disease: a critical reappraisal. Brain 111:27-62.

Boustany RM, Alroy J, Kolodny EH (1988) Clinical classification of neuronal ceroid-lipof uscinosis subtypes. Am J Med Genet [Suppl] 5:47-58.

Carpenter S (1988) Morphological diagnosis and misdiagnosis in BattenKufs disease. Am J Med Genet [Suppl] 5:85-91.

Cataldo AM, Barnett JL, Berman SA, Li J, Quarless S, Bursztajn S, Lippa C, Nixon RA (1995) Gene expression and cellular content of cathepsin $\mathrm{D}$ in Alzheimer's disease brain: evidence for early upregulation of the endosomal-lysosomal system. Neuron 14:671-680.

Elleder M, Sokolova J, Hrebicek M (1997) Follow-up study of subunit c of mitochondrial ATP synthase (SCMAS) in Batten disease and in unrelated lysosomal disorders. Acta Neuropathol (Berl) 93:379-390.

Ezaki J, Wolfe LS, Kominami E (1996) Specific delay in the degradation of mitochondrial ATP synthase subunit $\mathrm{c}$ in late infantile neuronal ceroid lipofuscinosis is derived from cellular proteolytic dysf unction rather than structural alteration of subunit c. J Neurochem 67:1677-1687.

Ezaki J, Tanida I, Kanehagi N, Kominami E (1999) A lysosomal proteinase, the late infantile neuronal ceroid lipofuscinosis gene (CLN2) prod$\mathrm{uct}$, is essential for degradation of a hydrophobic protein, the subunit $\mathrm{c}$ of ATP synthase. J Neurochem 72:2573-2582.

Fearnley IM, Walker JE, Martinus RD, Jolly RD, Kirkland KB, Shaw GJ, Palmer DN (1990) The sequence of the major protein stored in ovine ceroid lipofuscinosis is identical with that of the dicyclohexylcarbodiimidereactive proteolipid of mitochondrial ATP synthase. Biochem J 268:751-758.

Goebel HH, Klein H, Santavuori P, Sainio K (1988) Ultrastructural studies of the retina in infantile neuronal ceroid-lipofuscinosis. Retina 8:59-66.

Hablitz JJ, Johnston D (1981) Endogenous nature of spontaneous bursting in hippocampal pyramidal neurons. Cell Mol Neurobiol 1:325-334.

Hall NA, Lake BD, Dewji NN, Patrick AD (1991) Lysosomal storage of subunit $\mathrm{c}$ of mitochondrial ATP synthase in Batten's disease (ceroidlipof uscinosis). Biochem J 275:269-272.

Holtzman E (1989) Endocytosis and heterophagy. In: Lysosomes (Holtzman E, ed), pp 25-91. New York: Plenum.

Ii K, Ito H, Kominami E, Hirano A (1993) Abnormal distribution of cathepsin proteinases and endogenous inhibitors (cystatins) in the hippocampus of patients with Alzheimer's disease, parkinsonism-dementia complex on Guam, and senile dementia and in the aged. Virchows Arch A Pathol Anat Histopathol 423:185-194.

Ivy GO (1992) Protease inhibitors as a model for NCL disease, with special emphasis on the infantile and adult forms. Am J Med Genet 42:555-560.

Ivy GO, Schottler F, Wenzel J, Baudry M, Lynch G (1984) Inhibitors of lysosomal enzymes: accumulation of lipofuscin-like dense bodies in the brain. Science 226:985-987.

Johnson GV, Litersky JM, Whitaker JN (1991) Proteolysis of microtubule-associated protein 2 and tubulin by cathepsin D. J Neurochem 57:1577-1583.

Kominami E, Bando Y, Ii K, Hizawa K, Katunuma N (1984) Increases in cathepsins $\mathrm{B}$ and $\mathrm{L}$ and thiol proteinase inhibitor in muscle of dystrophic hamsters. Their localization in invading phagocytes. J Biochem (Tokyo) 96:1841-1848.

Kominami E, Tsukahara T, Bando Y, Katunuma N (1985) Distribution of cathepsins $\mathrm{B}$ and $\mathrm{H}$ in rat tissues and peripheral blood cells. J Biochem (Tokyo) 98:87-93.

Kominami E, Ezaki J, Muno D, Ishido K, Ueno T, Wolfe LS (1992) Specific storage of subunit c of mitochondrial ATP synthase in lysosomes of neuronal ceroid lipofuscinosis (Batten's disease). J Biochem (Tokyo) 111:278-282.

Ladror US, Snyder SW, Wang GT, Holzman TF, Krafft GA (1994) Cleavage at the amino and carboxyl termini of Alzheimer's amyloid-beta by cathepsin D. J Biol Chem 269:18422-18428.

Lane SC, Jolly RD, Schmechel DE, Alroy J, Boustany RM (1996) Apoptosis as the mechanism of neurodegeneration in Batten's disease. J Neurochem 67:677-683.

Matus A, Green GD (1987) Age-related increase in a cathepsin D like protease that degrades brain microtubule-associated proteins. Biochemistry 26:8083-8086.

Mercken M, Grynspan F, Nixon RA (1995) Differential sensitivity to proteolysis by brain calpain of adult human tau, fetal human tau and PHF-tau. FEBS Lett 368:10-14.

Murata M, Miyashita S, Yokoo C, Tamai M, Hanada K, Hatayama K, Towatari T, Nikawa T, Katunuma N (1991) Novel epoxysuccinyl peptides. Selective inhibitors of cathepsin B, in vitro. FEBS Lett 280:307-310.

Nakamura Y, Takeda M, Suzuki H, Morita H, Tada K, Hariguchi S, 
Nishimura T (1989) Lysosome instability in aged rat brain. Neurosci Lett 97:215-220.

Nakanishi H, Tominaga K, Amano T, Hirotsu I, Inoue T, Yamamoto K (1994) Age-related changes in activities and localizations of cathepsins D, E, B, and L in the rat brain tissues. Exp Neurol 126:119-128.

Nakanishi H, Kawachi A, Okada M, Fujiwara M, Yamamoto K (1996) Protective effect of MK-801 on the anoxia-aglycemia induced damage in the fluorocitrate-treated hippocampal slice of the rat. Brain Res 732:232-236.

Nakanishi H, Amano T, Sastradipura DF, Yoshimine Y, Tsukuba T, Tanabe K, Hirotsu I, Ohono T, Yamamoto K (1997) Increased expression of cathepsins $\mathrm{E}$ and $\mathrm{D}$ in neurons of the aged rat brain and their colocalization with lipof uscin and carboxy-terminal fragments of Alzheimer amyloid precursor protein. J Neurochem 68:739-749.

Nitatori T, Sato N, Waguri S, Karasawa Y, Araki H, Shibanai K, Kominami E, Uchiyama Y (1995) Delayed neuronal death in the CA1 pyramida cell layer of the gerbil hippocampus following transient ischemia is apoptosis. J Neurosci 15:1001-1011.

Nixon RA, Cataldo AM, Paskevich PA, Hamilton DJ, Wheelock TR, Kanaley-Andrews L (1992) The lysosomal system in neurons. Involvement at multiple stages of Alzheimer's disease pathogenesis. Ann NY Acad Sci 674:65-88.

Ohsawa Y, Nitatori T, Sato N, Waguri S, Higuchi S, Ishido K, Kominami E, Uchiyama Y (1993) Lysosomal cysteine and aspartic proteinases, acid phosphatase, and an endogenous cysteine proteinase inhibitor, cystatin $b$ in rat osteoclasts. J Histochem Cytochem 41:1075-1083.

Page AE, Fuller K, Chambers TJ, Warburton MJ (1993) Purification and characterization of a tripeptidyl peptidase I from human osteoclastomas: evidence for its role in bone resorption. Arch Biochem Biophys 306:354-359.

Palmer DN, Barns G, Husbands DR, Jolly RD (1986) Ceroid lipofuscinosis in sheep. II. The major component of the lipopigment in liver, kidney, pancreas, and brain is low molecular weight protein. J Biol Chem 261:1773-1777.

Palmer DN, Martinus RD, Cooper SM, Midwinter GG, Reid JC, Jolly RD (1989) Ovine ceroid lipof uscinosis. The major lipopigment protein and the lipid-binding subunit of mitochondrial ATP synthase have the same NH2-terminal sequence. J Biol Chem 264:5736-5740.

Reid WA, Valler MJ, Kay J (1986) Immunolocalization of cathepsin D in normal and neoplastic human tissues. J Clin Pathol 39:1323-1330.

Rider JA, Rider DL (1988) Batten disease: past, present, and future. Am J Med Genet [Suppl] 5:21-26.

Rider JA, Dawson G, Siakotos AN (1992) Perspective of biochemical research in the neuronal ceroid-lipof uscinosis. Am J Med Genet 42:519-524.

Saftig P, Hetman M, Schmahl W, Weber K, Heine L, Mossmann H, Koster A, Hess B, Evers M, von Figura K (1995) Mice deficient for the lysosomal proteinase cathepsin D exhibit progressive atrophy of the intestinal mucosa and profound destruction of lymphoid cells. EMBO J 14:3599-3608.

Saftig P, Peters C, von Figura K, Craessaerts K, Van Leuven F, De Strooper B (1996) Amyloidogenic processing of human amyloid precursor protein in hippocampal neurons devoid of cathepsin D. J Biol Chem 271:27241-27244.

Schägger H, von Jagow G (1987) Tricine-sodium dodecyl sulfatepolyacrylamide gel electrophoresis for the separation of proteins in the range from 1 to $100 \mathrm{kDa}$. Anal Biochem 166:368-379.

Towatari T, Nikawa T, Murata M, Yokoo C, Tamai M, Hanada K, Katunuma N (1991) Novel epoxysuccinyl peptides. A selective inhibitor of cathepsin B, in vivo. FEBS Lett 280:311-315.

Towbin H, Staehelin T, Gordon J (1979) Electrophoretic transfer of proteins from polyacrylamide gels to nitrocellulose sheets: procedure and some applications. Proc Natl Acad Sci USA 76:4350-4354.

Waguri S, Sato N, Watanabe T, Ishidoh K, Kominami E, Sato K, Uchiyama Y (1995) Cysteine proteinases in GH4C1 cells, a rat pituitary tumor cell line, are secreted by the constitutive and regulated secretory pathways. Eur J Cell Biol 67:308-318.

Whitaker JN, Rhodes RH (1983) The distribution of cathepsin D in rat tissues determined by immunocytochemistry. Am J Anat 166:417-428.

Wisniewski KE, Rapin I, Heaney-Kieras J (1988) Clinico-pathological variability in the childhood neuronal ceroid-lipofuscinoses and new observations on glycoprotein abnormalities. Am J Med Genet [Suppl] 5:27-46. 